\title{
Murine Developmental Control Genes
}

\author{
Michael Kessel and Peter Gruss
}

\begin{abstract}
Various strategies have been used to isolate genes that participate in the regulation of mouse development. Gene families that have been identified on the basis of their homology to motifs within Drosophila control genes or human transcription factor genes, namely homeobox (Hox), paired-box (Pax), and POU genes, can be compared with respect to gene organization, structure, and expression patterns. The functions of these genes can be analyzed molecularly in vitro and in vivo with the use of available mouse mutants or transgenic mice. In addition, it has been possible to generate gain- or loss-of-function mutations by random or targeted introduction of transgenes. Models derived from these studies can reveal the successive steps of developmental control on a genetic level.
\end{abstract}

$\mathrm{T}$ HE MODERN CONCEPT OF EMBRYOLOGY WAS FORMULATED in 1837 by Karl Ernst von Baer (1). Baer's views of embryogenesis subsequently inspired numerous naturalists of the 19th century to describe the events leading from the formation of germ layers to the complex structures of an individuum (2). Variations from normal development, induced physically, chemically, or occurring spontaneously were a driving force for the study of embryos $(3,4)$.

While classical geneticists followed up a phenotype to learn about a gene, the reverse situation is true for molecular biologists, who start with a gene and try to generate a phenotype. Numerous genes have been isolated by diverse approaches and remain to be tested for their role in development. The current status of reversed developmental genetics of the mouse, for which more than 1300 loci have been identified (4), is reviewed in this article.

\section{Strategies to Isolate Murine Developmental Control Genes}

There are several ways to identify murine developmental control genes. If starting from the abnormal phenotype of a mouse mutant, identification of the responsible gene is laborious and in most cases not altogether possible. The density of known genetic markers is not high enough, no clear structural differences exist between different chromosomes, and polytene chromosomes are not accessible. A well-studied developmental mutation, the $\mathrm{T}$ locus, has recently been cloned by microdissection of chromosomes, microcloning, extensive

M. Kessel and P. Gruss are at the Max-Planck-Institute of Biophysical Chemistry, Department of Molecular Cell Biology, 3400 Göttingen, FRG. genomic walking or jumping, and transcriptional analyses (5).

Tagging a chromosomal region by insertion of a transgene or retrovirus represents a second approach $(6,7)$. Developmental defects may become visible after breeding transgenic mice to homozygosity. For example, deformed limbs indicated insertion of a transgene into a locus essential for proper limb development. The transgene was subsequently used as a probe to clone the locus (7). $\beta$ galactosidase transgenes that lack promoters or enhancers have also been used ( 8 ). In this case, a developmentally regulated element can be identified after the embryos are stained by the $\beta$-galactosidase reaction, as $\beta$-galactosidase production will only be observed if integration has occurred near a regulatory element. The pattern of expression can then be used as a criterion for the occurrence of integration at a significant locus. This approach has the additional potential to generate an insertion mutation that can result in a loss of function mutant after the transgenic mouse is bred to homozygosity.

More commonly, mammalian genes have been isolated by exploiting information from a genetically more accessible organism, most often Drosophila. Key developmental control genes of the fruitfly have been cloned and characterized $(9,10)$, and many contain functional domains that are conserved within gene families of diverse members of the animal kingdom. Three sequence elements were suitable as molecular probes to screen for family members in the same or different species: the homeobox (10), the paired-box $(11,12)$, and the POU-box (13). The characteristics of these boxes and their murine forms are discussed below.

A number of other genes, which for various reasons are also thought to play regulatory roles during development, are mentioned here but not discussed. Many are members of gene families or share certain motifs. They include zinc-finger encoding genes (mouse krüppel-like 2, mkr2) (14), growth factor genes (fibroblast growth factor, FGF, transforming growth factor, TGF) (15), certain oncogenes (int-1, int-2, mos) (16), differentiation-inducing genes (MyoD) (17), and genes for transcription factors (18). The list continues to grow as new probes and new experimental tools such as the polymerase chain reaction (PCR) become available.

\section{Murine Hox, Pax, and POU Gene Families}

A homeobox is a region of $183 \mathrm{bp}$ that encodes a DNA-binding domain of 61 amino acids (19). It is present in three major classes of developmental control genes in Drosophila, namely maternal effect genes (for example, bicoid), segmentation genes (for example, fushi tarazu), and homeotic genes (for example, antennapedia) $(9,10)$. In the last $\mathbf{5}$ years more than $\mathbf{3 0}$ homeobox genes have been cloned from the murine genome. Most are similar to the prototype defined by the Drosophila antennapedia gene (Antp). These murine Hox genes are organized in four gene clusters each spanning more than 100 kilobases (kb) on chromosomes 6, 11, 15, and 2 (the Hox-1, Hox-2, Hox-3, and Hox-4 clusters, respectively) (Fig. 1) (20). Closer 


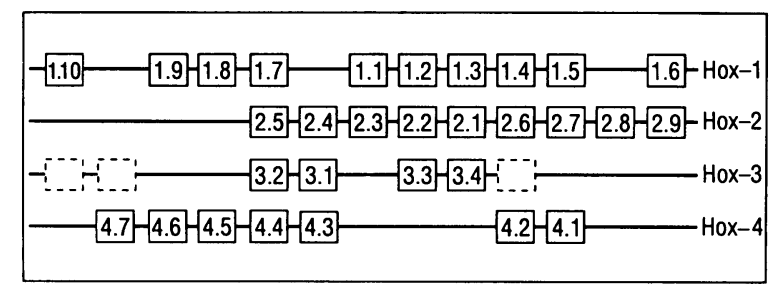

Fig. 1. Murine Hox clusters. The four murine clusters are located on chromosome 6 (Hox-1), chromosome 11 (Hox-2), chromosome 15 (Hox3 ), and chromosome 2 (Hox-4) (20). Distances are not drawn to scale; paralogous genes are vertically aligned $(23,24)$. Genes predicted from analysis of human clusters (62) are shown as dashed squares. Not all murine box sequences are published (10), in particular Hox-1.10, -1.9, and -1.8 (63), Hox-2.8 and -2.9 (37), and Hox-4.6 and -4.7 (48). Hox-3.3 and -3.4 were originally designated Hox-6.1 and -6.2 (64). Several genes of the Hox-4 cluster were originally designated Hox-5 genes, in particular Hox-4.2 (Hox5.1), Hox-4.4 (Hox-5.2), Hox 4.5 (Hox-5.3), Hox-4.6 (Hox-5.5), and Hox-4.7 (Hox-5.6) (20,48). Physical linkage between Hox-1.7 and Hox-1.1 was recently obtained (63), linkage between Hox-3.1 and Hox-3.3, as well as Hox-4.1 and Hox-4.2 is proven only in the human genome (62).

inspection of the homeobox sequences revealed that, within a cluster, they diverge increasingly from an Antp-like sequence. It is possible that an ancestral Hox gene was duplicated successively to form a gene cluster. At some time during the evolution of vertebrates, duplications of the cluster occurred, resulting in the four clusters typical of the murine and human genomes (21). Sequence comparisons reveal that almost identical proteins (for example, the Hox-1.1 and Hox-2.3 proteins) are encoded in different clusters (22). Similar proteins can be grouped into subfamilies of so-called paralogous genes, although not all clusters contain each paralog (Fig. 1). Furthermore, the two Drosophila homeobox gene clusters, antennapedia and bithorax, can be aligned with vertebrate paralogs on the basis of their homeobox sequences $(9,10,23,24)$.

Apart from the Hox clusters, several homeobox genes with more divergent box sequences have been found (Table 1), including two murine genes that are similar to the Drosophila engrailed homeobox (En-1 and En-2, on murine chromosome 5 and 1, respectively) (25, 26) and the evenskipped box (Evx-1 and Evx -2, murine chromosome 2) (27). The murine Cdx-1 gene on chromosome 18 was found with the Drosophila caudal box (28), and Hox-7 (chromosome 5) was cloned with the divergent Drosophila muscle-specific $m s h$ box and the murine Hox-1.6 box (29).
The Drosophila homeobox gene paired contains, in addition to the paired-type homeobox, a second motif, the paired box (11). The protein domains encoded by both types of boxes are predicted to fold into helix-turn-helix structures and thus may represent DNAbinding domains (30). Paired boxes are conserved in several genes of the fly and vertebrates $(11,12,30,31)$. The murine gene family that shows homologies to the paired box is designated Pax, and now includes eight members (Pax 1 through 8), only three of which (Pax 3,6 , and 7) contain a paired-type homeobox in addition to the paired box (31). No evidence for a clustered genomic organization has yet been obtained.

The analysis of genes encoding transcription factors from rat (Pit1, GHF-1, LF-Bl) (18) or human (Oct-1, Oct-2) $(32,33)$ revealed the presence of homeoboxes quite distinct from prototype antp-like boxes. The encoded homeodomain proteins, together with the unc86 protein from the nematode Caenorhabditis elegans, contain a second conserved region that lies upstream of the homeodomain and has been designated the POU-specific domain (13). The murine counterparts of Oct-1 and Oct-2 have been cloned (34). The other genes are also likely to have murine counterparts. POU-specific sequences were used as molecular probes to isolate cDNAs for a murine octamer factor (Oct-4) and other POU-genes of the rat (Brn-1, -2, -3, Tst-1) $(35,36)$.

Of course, it is not likely that all of the murine Hox, Pax, and POU genes necessarily have a regulatory role in murine embryogenesis, but their DNA binding capacity may be required for other purposes. Evidence is presented that some do indeed have the capacity to function as developmental control genes.

\section{Developmental Expression Patterns}

The involvement of developmental control genes during embryogenesis in Drosophila was discerned mainly from studies on mutants (9). In the mouse, comparable analyses have not yet been possible, thus establishing a hierarchy of the many putative mouse developmental control genes is difficult. One approach is to follow their temporal or spatial expression patterns. We deal initially with the distinctive properties of the Oct- 4 gene, then consider genes expressed along the complete rostrocaudal axis (Evx-1, Pax 1, Pax 2, Pax 3, En-1), the genes transcribed in very restricted domains (En-2, Krox-20, Hox 2.9), and finally the Hox genes with their partially overlapping expression domains and precise anterior expression

Table 1. Murine genes with conserved boxes.

\begin{tabular}{|c|c|c|c|c|}
\hline Gene & Chromosome & Embryonic expression & Type of box & References \\
\hline $\begin{array}{l}\text { Hox-1 } \\
\text { Hox-2 } \\
\text { Hox-3 } \\
\text { Hox-4 }\end{array}$ & $\begin{array}{r}6 \\
11 \\
15 \\
2\end{array}$ & $\begin{array}{l}\text { All genes are expressed in the CNS and most in } \\
\text { somites and derivatives. In addition, some are } \\
\text { expressed in limb buds and certain organs. }\end{array}$ & $\begin{array}{l}\text { antp } \\
\text { antp } \\
\text { antp } \\
\text { antp }\end{array}$ & $\begin{array}{c}(39,41,43) \\
(24,37,39,43) \\
(39,49) \\
(39,48)\end{array}$ \\
\hline Hox-7 & 5 & First arch mesenchyme, limb buds & $m s h$ & $(29)$ \\
\hline $\begin{array}{l}\text { En-1 } \\
\text { En-2 }\end{array}$ & $\frac{1}{5}$ & $\begin{array}{l}\text { Fore-, mid-, hindbrain, neural tube } \\
\text { Midbrain }\end{array}$ & $\begin{array}{l}\text { engrailed } \\
\text { engrailed }\end{array}$ & $\begin{array}{l}(25) \\
(26)\end{array}$ \\
\hline Evx-1 & 2 & Hindbrain, neural tube & evenskipped & $(27)$ \\
\hline Cdx-1 & 18 & Intestine, not in neuroectoderm & caudal & $(28)$ \\
\hline $\begin{array}{l}\text { Pax } 1 \\
\text { Pax } 2 \\
\text { Pax } 3\end{array}$ & $\begin{array}{l}2 \\
7 \\
\text { n.d.* }\end{array}$ & $\begin{array}{l}\text { Intervertebral disc, sternum, thymus } \\
\text { Hindbrain, neural tube, kidney } \\
\text { Mid-, hindbrain, neural tube }\end{array}$ & $\begin{array}{l}\text { Paired } \\
\text { Paired } \\
\text { Paired, prd- } \\
\text { homeobox }\end{array}$ & $\begin{array}{l}(12) \\
(31) \\
(31)\end{array}$ \\
\hline $\begin{array}{l}\text { Oct-1 } \\
\text { Oct-2 } \\
\text { Oct-4 }\end{array}$ & $\begin{array}{l}\text { n.d. } \\
\text { n.d. } \\
17\end{array}$ & $\begin{array}{l}\text { Ubiquitous } \\
\text { Fore-, mid-, hindbrain, neural tube } \\
\text { Oocytes, inner cell mass, germ cells, neuroectoderm }\end{array}$ & $\begin{array}{l}\text { POU } \\
\text { POU } \\
\text { POU }\end{array}$ & $\begin{array}{l}(34) \\
(34) \\
(35)\end{array}$ \\
\hline
\end{tabular}

* Not determined, n.d. 
boundaries (Fig. 2).

The only homeobox gene known to be expressed during the preimplantation phase is Oct-4, a transactivating transcription factor belonging to the POU family (35). Its gene products were detected by RNA analysis in situ and gel shift assays in the cell lineage consisting of the oocyte, inner cell mass, primordial germ cells of developing testes and ovaries, and female germ cells (35). Oct-4 gene products are, however, not detectable in sperm. Shortly after gastrulation Oct-4 is transcribed throughout the neuroectoderm, but by day 8.5 is restricted to primordial germ cells. It is possible that Oct-4 may act at the beginning of a cascade of control events.

The Evx-l gene is expressed immediately after gastrulation, beginning on day 7 of gestation. RNA can be detected at the posterior end of the embryo within the primitive ectoderm, and later in mesoderm and neuroectoderm as well (27). After neurulation, in a second phase of expression, Evx-l transcripts are found along the length of the neural tube posterior to the rhombencephalic isthmus, as are Pax 2 and Pax 3 transcripts. Pax 3 RNA, however, is also found further rostral, in the midbrain. A more specific pattern is observed in cross-sections of the neural tube, where different zones of the neuroepithelium or mantle layer are labeled by $\operatorname{Pax} 2, \operatorname{Pax} 3$, and Evx-1 probes $(27,31)$. Specific states of differentiation and proliferation during neurogenesis seem to be marked by these genes.

A feature peculiar to the paired box gene $\mathrm{Pax} l$ is the absence of transcription in the developing neuroectoderm, the major expression domain being the anlagen of the intervertebral discs (12). Like the other Pax genes, however, Pax 1 is expressed along the complete axis.

An En-l expression domain at day $\mathbf{1 2 . 5}$ of gestation extends from the midbrain down the entire spinal cord. However, at earlier stages, the En-l expression more closely resembles the restricted pattern of En-2, in that it is expressed in a band around the midbrainhindbrain junction (26). Both Hox-2.9 and the zinc finger gene Krox-20 have restricted expression domains in the segmented rhombencephalon (Fig. 2), the Hox-2.9 domain in rhombomere 4 being flanked by the two Krox-20 domains in rhombomeres 3 and 5 $(37,38)$. As with En-1, Hox-2.9 RNA is also found in later stages in more posterior regions of the neural tube (37).

The expression patterns of most of the Hox genes seem to follow similar principles. They typically begin to be expressed during early gastrulation, when the first mesoderm cells leave the primitive streak (day 7.5 to 8.5 of gestation). Most Hox genes are expressed in the mid-gestation phase (day 9 to 12), a time when organogenesis prevails (39). A characteristic expression domain is the neural tube, the only exception being Cdx-l (28). In addition, most genes are also expressed in the somites and sclerotomes. A relatively sharp anterior border of expression and a less well-defined posterior boundary are typical in ectoderm and mesoderm. Thus, different overlapping regions along the anteroposterior axis are characterized by different transcribed sets of Hox genes (Fig. 2).

The generation of such expression patterns has been studied in transgenic mice $(40,41)$. A detailed study of the dynamics of the expression was carried out with constructs representing fusions between Hox promoter sequences and a reporter $\beta$-galactosidase gene (Hox-1.1-lacZ) (41). The transgene is initially (day 7.5 to 8) expressed in the allantois, subsequently in neuroectoderm, and later also in mesoderm. The anterior boundaries of expression are established very early. In situ analyses indicate that patterns of expression may follow a general principle in that boundaries of Hox expression that extend more anteriorly in the mesoderm seem to reflect earlier initiation and cessation of expression. Thus, for example, the period of transcription of the very anteriorly expressed genes Hox-1.6 and Hox-2.9 is earlier than, for example, that of Hox-2.5, and Hox-1.6 and Hox-2.9 RNAs are no longer detectable at later stages (day 12) (42).

The linear order of the clustered Hox genes along the chromosome correlates with the spatial order of their anterior borders of expression (Fig. 2) (24). The more $5^{\prime}$ a gene lies, the more posterior its boundary is located. The only exceptions seem to be the most 3 'located genes Hox-1.6 and Hox-2.9. This rule also holds for the
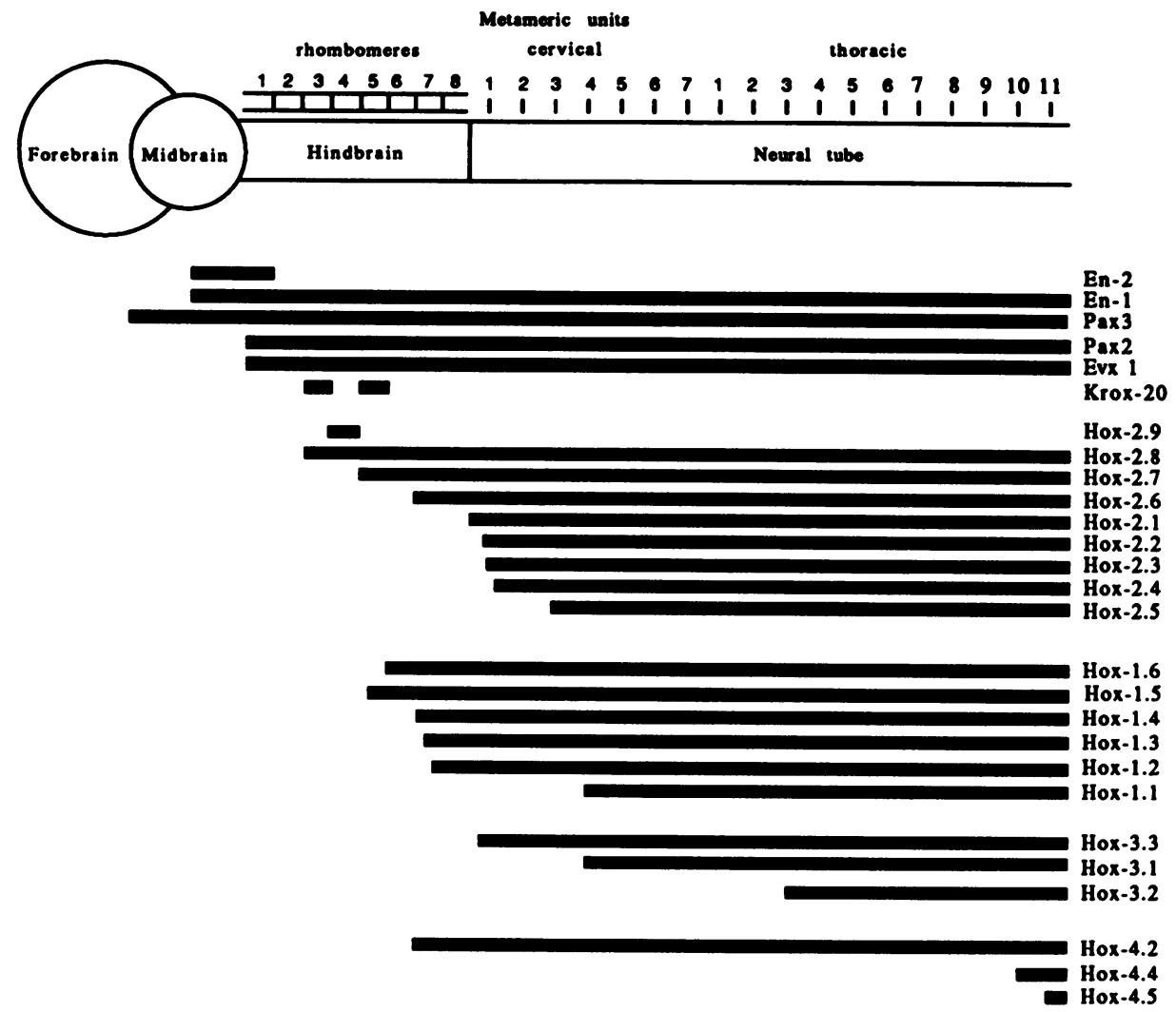

Fig. 2. Anterior expression boundaries in the neuroectoderm. The indicated anterior borders have not been obtained at the same embryological stage in each study $(24-27,31,37-39,41,43)$. However, they reflect in principle the boundaries characterizing a gene at its major expression time (usually day 12.5 of gestation, except Hox-1.6 and Hox-2.9). Assignment to specific rhombomeres (day 9.5) has only been obtained for Hox-2 genes and Krox-20 (37, 38). Metameric units are given as the levels of prevertebrae on day $\mathbf{1 2 . 5}$ or as rhombomeres on day 9.5 
Drosophila genes after alignment of the clusters. Posterior body regions are specified by $5^{\prime}$ genes like abdominal $\mathrm{B}$, and $3^{\prime}$ genes like labial specify anterior parts (9). Anterior borders of the paralogous Hox-1.4, -2.6, and -5.1 genes have been demonstrated to be almost identical (43). In a different group, consisting of the paralogous Hox-1.7, -2.5, -3.2, and -5.2 genes, however, quite divergent boundaries have been observed (44).

A characteristic of Hox and Pax 1 expression patterns is their transcription in segmented tissues such as the prevertebrae or the rhombomeres. In the midgestation mouse embryo, the paraxial mesoderm is the most obviously segmented structure. The initial metameric unit is the somite, which differentiates into sclerotome and dermomyotome, then forms the vertebrae, dermis, and muscles. In situ analysis of many Hox RNAs has demonstrated segmental expression of representatives of each of the four Hox clusters in the mesoderm-derived somites and sclerotomes (39). Hox RNA is always detected several metameric units more caudal in mesoderm than in ectoderm derivatives (39).

At day 9.5 of gestation, segmentation can also be detected in the neuroectoderm, where the developing hindbrain is segmented into eight rhombomeres. The anterior expression borders of the five Hox- 2 genes from the $3^{\prime}$ end of the cluster fall on rhombomere boundaries, while the other four Hox- 2 genes have borders in the neural tube, where no metameric units are detectable (37).

Hox genes can be induced with gene-specific kinetics by retinoic acid (RA) in teratocarcinoma cells, either transcriptionally or posttranscriptionally (45). The correlation of the position of a gene in the cluster with a specific order of the expression patterns has been demonstrated for the human Hox-2 genes in the teratocarcinoma cell line NT2 (46). The Hox-2 gene located most $3^{\prime}$ responds to low concentrations of RA, while increasingly higher concentrations are needed to turn on successively more $5^{\prime}$ positioned genes. At a given concentration of $\mathrm{RA}$, the $3^{\prime}$ genes are induced very rapidly, while RNAs from genes positioned successively more $5^{\prime}$ appeared after a few days of treatment. This slower rate of onset for the $5^{\prime}$ genes raises questions about the primary events preceding Hox gene activation. Growth factors such as FGF and TGF- $\beta 2$ and their respective receptors may be involved in the tempered control. From studies in Xenopus laevis it is known that these growth factors are involved in mesoderm induction, which is accompanied by activation of homeobox genes $(15,47)$. Genes involved in the transmittance of signals from cell to cell may represent an earlier phase in a hierarchical cascade regulating development than the nuclear transcriptional regulators.

It is striking that the correlation between expression domains and locations of a Hox gene in the cluster can also be followed in a small morphogenetic field, the developing limb. The expression of Hox$4.2,-4.4,-4.5,-4.6$, and -4.7 have been compared in the developing limb bud, a tissue derived from lateral mesoderm (48). A dynamic, temporally restricted pattern of expression was observed in the posterior limb area, where RNA from $3^{\prime}$ genes appeared earlier and more proximal, and $5^{\prime}$ genes later and more distal. Among other genes expressed in the limb are Hox-1.1 and Hox-7 (29). The only Hox gene product found predominantly in the anterior zone of the limb bud is the murine equivalent of Hox-3.3, which was studied in the mouse limb with antibodies to the Xenopus protein (49). The expression of Hox genes can also be correlated with other functional parameters, such as the ability of retinoic acid to act as a potential morphogen in the limb bud (50). Retinoic acid can mimic the activity of the zone of polarizing activity, which generates the correct positional information for limb formation by secreting a diffusible morphogen. Thus, the close connection between RA and Hox gene expression is now evident from in vitro and in vivo systems. The role of morphogens in the regulation of development will be a major focus of future research.

The expression of many Hox and Pax genes is not restricted to embryonic central nervous system and prevertebrae. Other expression domains include the developing kidney (Hox-1.1, -2.3, -1.3, 2.1, Cdx-1, Pax 2), the lung (Hox-1.3, -2.1), testes (Hox-1.4), intestine (Hox-1.4 and -1.6), thymus, sternum (Pax 1), and germ cells (Oct-4) $(12,28,31,35,39)$. The significance of these expression sites remains unclear, and more precise analyses of expression including antibody and whole-mount in situ techniques are mandatory.

The interpretation of complex expression patterns, while difficult, can sometimes be facilitated by the study of perturbations of the normal paths of development. Historically, the amphibian Xenopus and the chick have been used as experimental systems accessible for embryonic manipulations, whereas rodents were preferred for teratologic studies. Today, classical experiments are being repeated to analyze the behavior of homeobox genes in such defined systems.

\section{Reversed Genetics}

How can the developmental functions of the growing number of murine candidate genes be determined? Initial steps are definition of the murine gene products on the basis of cDNAs, determination of the chromosomal localization, and establishment of expression patterns. Often, important aspects of the homologous gene in other species are already known or can be obtained, as genetics has been intensively studied in Drosophila and embryological aspects in Xenopus. Thus it was obvious from the beginning that many of the Hox, Pax, and POU genes encode DNA binding proteins, with helixturn-helix domains (10). As predicted from the extreme conservation of the homeodomain recognition helix, even such diverse proteins as engrailed and evenskipped bind to very similar sequences all of which contain a core sequence of ATTA. What structural features are required to achieve further specificities remain to be determined $(10,51)$.

Several known transcription factors turned out to be encoded by homeobox genes. This was taken as supportive evidence that, in general, a function of homeodomain proteins is to modulate transcription. Activation or repression of transcription has been demonstrated by cotransfection of reporter and expression vectors for Drosophila homeobox genes and for octamer factor genes (10, 33), and may be the same for murine Hox and Pax genes. The establishment of such assays will facilitate study of molecular function, including mutational analyses, analysis of cooperating factors, and identification of target genes.

To understand the developmental function of a gene, it is necessary to look at the whole embryo. A genetic analysis studying the effects of absence (loss of function) or misregulation (gain of function) of a gene is required.

Of the murine genes mentioned above, only the Pax 1 gene could be correlated with a known developmental mutant (52). Pax 1 is an exception in that it lacks a homeodomain and is not expressed in neuroectoderm. Its main expression domain at day 12 of gestation includes the intervertebral discs, the sternum, and the thymus (12). The chromosomal location of $\operatorname{Pax} 1$ is very close to the position of the skeletal mutant undulated. These mice suffer from pathological development of intervertebral discs, which is visible as a kinky tail in homozygotes. With the use of restriction length polymorphisms, cloning by the polymerase chain reaction, and sequencing, a point mutation was demonstrated in the Pax 1 paired-box specific for undulated mice (52). Proof for Pax 1 mutations being responsible for the undulated phenotype was recently obtained from two independent allelic mutants (53). All three undulated mutants show abnor- 
malities in the major expression domain of the Pax 1 gene. This allelic series of Pax 1 mutants will be ideal for the elucidation of the role of Pax 1 during sclerotome differentiation.

Although each newly mapped gene has to be tested for the availability of a mutant, the matching pairs are not likely to be found. Introduction of manipulated genes into the germ line of mice is a way to reverse genetics and generate a mutant for a particular gene. Numerous transgenic mice have been described that bear random integrations of transgenes in their genome. Expression is dependent on site of integration, choice of promoter or enhancer, and presence of regulatory signals, which may lie unrecognized in untranslated $5^{\prime}$ and $3^{\prime}$ regions, introns, or coding sequences. Because of this complexity, specific regulation, which should optimally be inducible at a desired time point, is not readily obtainable for most transgene expression systems.

Transgenic mice have been used to generate gain-of-function mutants for the Hox-1.4 and the Hox-1.1 genes. The Hox-1.4 gene under its own promoter was modified by exchanging the $3^{\prime}$ untranslated region for SV40 viral sequences (54). The rationale was to stabilize the message and thus achieve overexpression in tissues where the Hox-1.4 promoter is active. These altered mice had a functional stenosis of the colon, a disease known as megacolon. The cause is improper innervation of the colon, probably due to the lack of ganglia of the enteric plexi responsible for the peristaltic activity. These ganglia are derivatives of the neural crest, which may be the site of interference of the transgene with proper development. However, further study will be necessary to establish the function of Hox-1.4, as it is also expressed in the gut mesenchyme.

An expression vector consisting of the $\beta$-actin promoter linked to genomic Hox-1.1 sequences was used to generate a Hox-1.1 gain of function mutant (55). As predicted, the ubiquitously active actin promoter directed expression of Hox-1.1 in practically all tissues, albeit at relatively low levels. The consequences of this expression are lethal, with transgenic mice surviving only shortly after birth. Mice were born with a consistent phenotype, open eyelids, malformed external ears, and cleft secondary palate. The cause of these craniofacial abnormalities was tentatively assigned to disruptive interferences with programs directing cranial neural crest cells. The relevant neural crest cells are all derived from a narrow region of the crest at the level of rhombomeres 2 and 3 , from which cells migrate predominantly to the first branchial arch. A similar craniofacial phenotype results from teratological doses of RA, again an indication of the close connection of the putative morphogen with a developmental control gene.

More recently, variations in mesodermal derivatives were observed in Hox-1.1 transgenics (56). In normal mice the first cervical vertebra (atlas) contains no vertebral body, while the second vertebra (axis) possesses an additional ossification centre (dens axis). Transgenic atlas and axis each possess one vertebral body, which makes them similar to more posterior cervical vertebrae. Moreover these mice have an additional intervertebral disc and an additional vertebra (proatlas) at the cranio-cervical transition. The cause of these variations probably is incorrect programming during somite differentiation and can be traced back to the postimplantation phase around day 9 of gestation, a timing similar to that postulated for the Hox-1.1 transgene effect on the ectoderm. Both in the neuroectoderm and in the somitic mesoderm the abnormalities occur anterior of the normal boundaries of Hox-1.1 expression. The vertebral variations resemble posterior transformations, which according to the model of E. B. Lewis are predicted for a gain-of-function mutant of a homeotic gene (57). In conclusion, reverse genetics has revealed some intrinsic capacities of Hox-1.1 for regulatory control functions, which may be defined in future experiments on the embryonic level.
A procedure to produce targeted loss-of-function mouse mutants has recently been elaborated and the key steps have been demonstrated successfully (58). A sequence is inserted into a target gene by homologous recombination in embryonic stem cells (ES cells), thereby deleting the functional information. After isolating the mutated ES cells with the desired recombination, a few cells are injected into blastocysts and contribute to the generation of a chimaeric mouse. If they also contribute to the germ line, heterozygous and homozygous mice can be bred. A growing number of genes have been inactivated in ES cells by such approaches, including En-2, Hox-1.1, and other genes of the Hox clusters (59). Recently, transmission through the germ line was reported for inactivating mutations of the HPRT-gene, the protooncogene c-abl, the $\beta 2$-microglobulin, and the En-2 genes (60).

The specificity of mutations generated by reverse genetics is technically and conceptually still limited. Severe mutations may be lethal, and loss-of-function mutants may give information on the first vital function only. On the other hand the duplication of genes may also provide redundant genetic material, which may substitute for an inactivated copy. It may turn out, therefore, that quite sophisticated mutations have to be introduced in order to appreciate the tremendous possibilities of this approach.

\section{Conclusion}

We have described structures, expression patterns, and functional aspects of murine Pax, Hox, and POU genes. Extensive parallels between Drosophila and mouse genes indicate that the same basic genetic principles apply to these diverse species. In both organisms, the definition of the rostrocaudal axis is tightly connected with segmentation. While in insects this is obvious throughout life, in mammals it is most evident in embryonic stages. Early in development, segmentation in the mammalian head is dominated by the neuroectoderm. The rhombomeric divisions of the neural tube correlate with the segmented anatomy of the branchial arches. In the trunk, segmentation is overt only in the paraxial mesoderm, while the ectodermal spinal cord is not segmented. In higher vertebrates the formation of limbs from unsegmented lateral mesoderm requires the definition of secondary axes after the major embryonic decisions along the rostrocaudal axis of the body have been carried out.

The role of the mammalian Pax, Hox, and POU genes in these processes is still not entirely known. Positional information along the rostrocaudal as well as the limb axes seems to be provided by morphogens like retinoic acid and growth factors. The zone of polarizing activity at the posterior limb margin has been discussed as a source area, from which a morphogen gradient is established (48). Developmental control genes apparently interpret such information, as indicated by their overlapping expression patterns along the anteroposterior axis and their response to morphogens in model systems (45-50). Some genes could be involved in the initial establishment of the axes which may include the generation of segments, while others could specify segment or cell identities. Inductive interactions, possibly homeogenetic inductions across germ layers, may further be involved in the definition of body regions (61). Cell fates and programs may finally be specified by the combination of developmental control proteins present in the nucleus. Expansion from one Hox cluster to four by duplication may be an evolutionary strategy required in order to achieve the complexity levels of higher vertebrates.

Undoubtedly more members of more gene families will be isolated. The study of their molecular function will include biochemical techniques and transgenic mice. Improvement of mouse embryo culture will allow the application of refined manipulative method- 
ology, and study of zebrafish genetics will help close the gap between insects and mammals. Chemical approaches as well as the described techniques of reversed genetics in transgenic animals should increase the number of available mouse mutants. It seems within reach that the knowledge of "molecular functions" and "developmental functions" will merge into an understanding of the genetic networks, hierachies, or programs directing embryonic development in higher vertebrates.

\section{REFERENCES AND NOTES}

1. "I would like, therefore, to attempt to lead you to a deeper insight into the reproduction and development of organized bodies by giving an account of observed facts, and to show you how these bodies are neither preformed nor, as is commonly supposed, do they come forth suddenly, at a particular moment, out of a formless mass." As translated from the German, K. E. von Baer, Über die Entwickelungsgeschichte der Thiere (Königsberg 1837).

2. Outstanding embryologists including W. Roux, H. Driesch, T. Boveri, H. Spemann, R. G. Harrison, S. Horstadius, T. H. Morgan, C. H. Waddington, and many others laid the foundations of our knowledge on ontogeny; J. M. Oppenheimer, Essays in the History of Embryology and Biology (MIT Press, Cambridge, MA, 1967).

3. W. Bateson, Materials for the Study of Variation (Macmillan, New York, NY, 1984).

4. M. F. Lyon and A. G. Searle, Genetic Variants and Strains of the Laboratory Mouse (Oxford Univ. Press, Oxford, 1989).

5. B. G. Herrmann, S. Labeit, A. Poustka, T. R. King, H. Lehrach, Nature 343, 617 (1990).

6. R. Jaenisch et al., Cell 32, 209 (1983).

7. R. P. Woychik, T. A. Stewart, L. G. Davis, P. D’Eustachio, P. Leder, Nature 318 , 36 (1985).

8. N. D. Allen, ibid. 333, 852 (1988); R. Kothary et al., ibid. 335, 435 (1988); A. Gossler, A. L. Joyner, J. Rossant, W. C. Skarnes, Science 244, 463 (1988)

9. P. W. Ingham, Nature 335, 25 (1988); M. Pfeifer, F. Karch, W. Bender, Genes Dev. 1, 891 (1987); M. Akam, Cell 57, 357 (1989); W. J. Gehring, Science 236, 1245 (1987).

10. M. P. Scott, J. W. Tamkum, G. W. Hartzell, III, Biochim. Biophys. Acta 989, 25 (1989).

11. D. Bopp, M. Burri, S. Baumgartner, G. Frigerio, M. Noll, Cell 47, 1033 (1986).

12. U. Deutsch, G. Dressler, P. Gruss, ibid. 53, 617 (1988)

13. W. Herr et al., Genes Dev. 2,1513 (1988).

14. K. Chowdhury, U. Deutsch, P. Gruss, Cell 48, 771 (1986).

15. J. C. Smith, Development 105, 665 (1989).

16. D. G. Wilkinson, J. A. Bailes, A. P. McMahon, Cell 50, 79 (1987); G. M Shackleford, H. E. Varmus, ibid. 50, 89 (1987); D. G. Wilkinson, G. Peters, C. Dickson, A. P. McMahon, EMBO J. 7, 691 (1988); N. Sagata, M. Oskarson, T. Copeland, J. Brumbaugh, G. F. Vande Woude, Nature 335, 519 (1989).

17. R. L. Davis, H. Weintraub, A. B. Lassar, Cell 51, 987 (1987).

18. H. A. Ingraham et al., ibid. 55, 519 (1988); M. Bodner et al., ibid. 55, 505 (1988); M. Frain et al., ibid. 59, 145 (1989).

19. W. McGinnis, M. Levine, E. Hafen, A. Kuroiwa, W. J. Gehring, Nature 308, 478 (1984); W. McGinnis, R. L. Garber, J. Wirz, A. Kuroiwa, W. J. Gehring, Cell 37 403 (1984); M. P. Scott, A. J. Weiner, Proc. Natl. Acad. Sci. U.S.A. 81, 3115 (1984).

20. G. Martin et al., Nature 325, 21 (1987); D. Duboule et al., Genomics 7, 458 (1990).

21. M. Fibi et al., Development 102, 359 (1988); C. Kappen, K. Schughart, F. H Ruddle, Proc. Natl. Acad. Sci. U.S.A. 86, 5459 (1989).

22. M. Kessel, F. Schulze, M. Fibi, P. Gruss, Proc. Natl. Acad. Sci. U.S.A. 84, 5306 (1987); F. Meijlinck et al., Nucleic Acids Res. 15, 6773 (1987).

23. E. Boncinelli et al., Human Reprod. 3, 880 (1988).

24. S. Gaunt, P. T. Sharpe, D. Duboule, Development 104 (Suppl.), 169 (1988); D. Duboule and P. Dolle, EMBO J. 8, 1497 (1989); A. Graham, N. Papalopulu, R. Krumlauf, Cell 57, 367 (1989).

25. A. Joyner and G. Martin, Genes Dev. 1, 29 (1987).

26. C. Davis, S. E. Noble-Topham, J. Rossant, A. Joyner, ibid. 2, 361 (1988); C. A. Davis and A. L. Joyner, ibid. 2, 1736 (1988); D. Davidson, E. Graham, C. Sime, R. Hill, Development 104, 305 (1988).

27. H. Bastian and P. Gruss, EMBO J. 9, 1839 (1990)

28. P. Duprey et al., Genes Dev. 2, 1647 (1988).

29. R. E. Hill et al., ibid. 3, 26 (1989); B. Robert, D. Sassoon, B. Jacq, W. Gehring, M Buckingham, EMBO J. 8, 91 (1989).

30. D. Bopp, E. Jamet, S. Baumgartner, M. Burri, M. Noll, EMBO J. 8, 3547 (1989).
31. G. Dressler et al., Development 109, 787 (1990); H. Nornes et al., ibid., p. 797; C Walther et al., in preparation; M. Goulding et al., in preparation.

32. R. A. Sturm, G. Das, W. Herr, Genes Dev. 2, 1582 (1988).

33. H.-S. Ko, P. Fast, W. McBride, L. M. Staudt, Cell 55, 135 (1988); R. G. Clerc, L. M. Corcoran, J. H. LeBowitz, D. Baltimore, P. A. Sharp, Genes Dev. 2, 1570 (1988); C. Scheidereit et al., Nature 336, 8 (1988); M. M. Müller, S. Ruppert, W. Schaffner, P. Matthias, ibid. 336, 544 (1988).

34. A. Hatzopoulos et al., Development 109, 349 (1990); N. Suzuki et al., in preparation.

35. H. R. Schöler, R. Balling, A. K. Hatzopoulos, N. Suzuki, P. Gruss, EMBO J. 8 , 2551 (1989); H. R. Schöler, A. K. Hatzopoulos, R. Balling, N. Suzuki, P. Gruss, ibid. 8, 2543 (1989); H. R. Schöler, S. Ruppert, N. Suzuki, K. Chowdury, P. Gruss, Nature 344, 435 (1990); K. Okamoto et al., Cell 60, 461 (1990); H Schöler, G. R. Dressler, R. Balling, H. Rohdewoldt, P. Gruss, EMBO J. 9, 2185 (1990).

36. X. He et al., Nature 340, 36 (1989).

37. D. G. Wilkinson, S. Bhatt, M. Cook, E. Boncinelli, R. Krumlauf, ibid. 341, 405 (1989); P. Murphy, D. R. Davidson, R. E. Hill, ibid., p. 156

38. D. G. Wilkinson, S. Bhatt, P. Chavrier, R. Bravo, P. Charnay, ibid. 337, 461 (1989).

39. For review of earlier papers see P. Holland and B. Hogan, Genes Dev. 2, 773 (1987); M. S. Featherstone, A. Baron, S. J. Gaunt, M.-G. Mattei, D. Duboule, Proc. Natl. Acad. Sci. U.S.A. 85, 4760 (1988); K. Mahon, H. Westphal, P. Gruss, Development 104 (Suppl.), 187 (1988); K. Schughart, M. Utset, A. Awgulewitsch, F. H. Ruddle, Proc. Natl. Acad. Sci. U.S.A. 85, 5582 (1988); A. Graham et al., Genes Dev, 2,1424 (1988); P. T. Sharpe, J. R. Miller, E. P. Evans, M. D. Burtenshaw, S. J. Gaunt, Development 102, 397 (1988); H. Le Mouellic, H. Condamine, P. Brulet, Genes Dev. 2, 125 (1988); L. D. Bogarad, Dev. Biol. 133 537 (1989); P. Dolle and D. Duboule, EMBO J. 8, 1507 (1989); B. Galliot et al., Development 107, 343 (1989); J. Erselius, in preparation.

40. J. Zakany, C. K. Tuggle, M. D. Patel, M. C. Nguyen-Huu, Neuron 1, 679 (1988).

41. A. Püschel, R. Balling, P. Gruss, Development 108, 435.

42. A. Baron et al., EMBO J. 6, 2977 (1987).

43. S. J. Gaunt, R. Krumlauf, D. Duboule, Development 107, 131 (1989).

44. J. Erselius, M. Goulding, P. Gruss, EMBO J., in press.

45. A. M. Colberg-Poley, S. D. Voss, K. Chowdury, P. Gruss, Nature 314, 713 (1985); A. M. Colberg-Poley, A. W. Püschel, C. Dony, S. D. Voss, P. Gruss, Differentiation 35, 206 (1987); J. Deschamps, R. De Laaf, L. Joosen, F. Meijlink, O. Destree, Proc. Natl. Acad. Sci. U.S.A. 84, 1304 (1987); F. Mavilio, A. Simeone, E. Boncinelli, P. Andrews, Differentiation 38, 73 (1988).

46. A. Simeone et al., in press.

47. A. Ruiz i Altaba and D. A. Melton, Nature 341, 33 (1989).

48. P. Dolle, J.-C. Izpisua-Belmonte; H. Falckenstein, A. Renucci, D. Duboule, ibid., p. 767.

49. G. Oliver, C. V. E. Wright, J. Hardwicke, E. M. De Robertis, Cell 55, 1017 (1988).

50. J. P. Brockes, Neuron 2, 1285 (1989).

51. J. Treisman, P. Gönczy, M. Vashishtha, E. Harris, C. Desplan, Cell 59, 553 (1989); Y. Q. Qian, ibid., p. 573.

52. R. Balling, U. Deutsch, P. Gruss, ibid. 55, 531 (1988).

53. R. Balling, personal communication.

54. D. J. Wohlgemuth, R. R. Behringer, M. P. Mostoller, R. L. Brinster, R. D. Palmiter, Nature 337, 464 (1989).

55. R. Balling, G. Mutter, P. Gruss, M. Kessel, Cell 58, 337 (1989)

56. M. Kessel, R. Balling, P. Gruss, ibid. 61, 301 (1990)

57. E. B. Lewis, Nature 276, 565 (1978).

58. M. R. Capecchi, Science 244, 1288 (1989).

59. A. Zimmer and P. Gruss, Nature 338, 150 (1989); A. L. Joyner, W. C. Skarnes, J. Rossant, ibid., p. 153.

60. S. Thompson, A. R. Clarke, A. M. Pow, M. L. Hooper, D. W. Melton, Cell 56, 313 (1989); P. L. Schwartzberg, S. P. Goff, E. J. Robertson, Science 246, 799 (1989); M. Zijlstra, E. Li, F. Sajiadi, S. Subramani, R. Jaenisch, Nature 342, 435 (1989); B. Koller et al., Proc. Natl. Acad. Sci. U.S.A. 86, 8927 (1989); A. Joyner, personal communication.

61. E. De Robertis, G. Oliver, C. V. E. Wright, Cell 57, 189 (1989)

62. D. Acampora et al., Nucleic Acids Res. 17, 10385 (1989).

63. H. Haack et al., personal communication.

64. P. T. Sharpe, J. R. Miller, E. P. Evans, M. D. Burtenshaw, S. J. Gaunt, Development 102, 397 (1988).

65. We thank many colleagues for the contribution of preprints and unpublished results, and all members of this laboratory for generously sharing results and ideas. Supported by the Max-Planck-Gesellschaft.

4 April 1990; accepted May 1990 
EXTENDED PDF FORMAT

\section{Science \\ \IAAAS}

Murine developmental control genes

M Kessel and P Gruss (July 27, 1990)

Science 249 (4967), 374-379. [doi: 10.1126/science.1974085]

Editor's Summary

This copy is for your personal, non-commercial use only.

Article Tools Visit the online version of this article to access the personalization and article tools:

http://science.sciencemag.org/content/249/4967/374

Permissions Obtain information about reproducing this article: http://www.sciencemag.org/about/permissions.dtl

Science (print ISSN 0036-8075; online ISSN 1095-9203) is published weekly, except the last week in December, by the American Association for the Advancement of Science, 1200 New York Avenue NW, Washington, DC 20005. Copyright 2016 by the American Association for the Advancement of Science; all rights reserved. The title Science is a registered trademark of AAAS. 